\title{
Indications of Machiavellianism in Ethical Decision of Senior Accountants
}

\author{
Febryandhie Ananda ${ }^{1}$, Doni Marlius ${ }^{2}$ \\ \{febryandhie@akbpstie.ac.id ${ }^{1}$, donimarlius@akbpstie.ac.id $\left.{ }^{2}\right\}$ \\ ${ }^{1}$ Sekolah Tinggi Ilmu Ekonomi KBP, Padang, Indonesia, ${ }^{2}$ Akademi Keuangan dan Perbankan \\ Pembangunan Padang, Indonesia
}

\begin{abstract}
This research is a continuation of previous research that found inconsistent results. The purpose of this research is to examine the Machiavellianism relationship with ethical decisions in profit management in Indonesia in two forms of manipulation, i.e. manipulation of operations and manipulation of accounting. The data collection method in this study used a total of 70 respondents. Machiavellianism not influence the ethical decision of profit management in the public accountant office in West Sumatera. This is because the customary system of ABSSBK (Adat Basandi Syara' - Syara' Bersandi Kitabullah) in West Sumatera has an impact on the character of Senior Accountant, and there is a significant difference between manipulation of operations and manipulation of accounting.
\end{abstract}

Keywords: Senior Accountant, Machiavellian, Ethical Decision

\section{Introduction}

Fraud Triangle describes three factors that can explain the behavior of cheating in financial reporting, i.e. Opportunity, incentive and attitude. However, out of these three factors, the relative attitudes of the mystery factor is still not much thorough [1]. This raises the challenge and the opportunity to further test the relationship between attitude or rationalization by fraudulent behavior.

Attitude is one form of predispositions. In addition to attitudes, predispositions can also appear in character trait form. Compared with attitudes that can easily change, the second form of predispositions tends to be stable [2]. Thus, this second form is closer to observing behavior. One form of character traits is Machiavellianism. Research by [2] found that there was a link between Machiavellianism with the behavior of fraudulent financial reporting. Other studies by [3] also found the same thing that Machiavellianism could explain the behavior of fraudulent financial reporting.

This research is a continuation of research [3] and [4] which finds inconsistent results. [3] found the result that Chinese professional accountants further forgive the manipulation of accounting compared to manipulation of operations. This results in contrast to previous research results which found that professional accountants, managers and students in America are less forgiving of manipulation of operations than manipulation of accounting. This may be due to differences in the ethical culture between East and West [5].

Meanwhile [4] it is found that there is no connection between Machiavellianism and profit management ethics in Indonesia. We argue that the inconsistency of this result is because [4] it does not distinguish two forms of profit management, namely the manipulation of operations 
with the manipulation of accounting. [3] discovered that the effects of Machiavellianism tended to be stronger for manipulation of operation compared to manipulation of accounting.

This research is very important to confirm the results of previous research conducted in Indonesia by [4] and in China by [3] as well as [6] in West Sumatera with customary system ABS-SBK ("Syara" - Syara ' Bersandi kitabullah). This research will be conducted by a survey method with a sample of senior accountants. The inconsistencies of previous research results were conducted by [4] and the results were contrasted by [3] In contrast to the problems formulated in this research.

Previous studies show that profit management can be good and bad. Jooste (2013) stated that poor profit management hides real operating performance by creating artificial accounting entries or making forecasts beyond fair points. While the management of good profit, is the proper practice and part of the operation manages the business well, and will provide added value for shareholders. The action of manipulating profit may be justified by the investor throughout the action that the company benefits.

Kolhberg (1981), in [8] explaining that the ethical orientation has relationships with ethical dimensions such as Machiavellian. The Nature of Machiavellian is was introduced by an Italian political philosopher named Nicollo Machiavellian (1469-1527). Machiavellianism is defined as a process whereby the manipulator earns more reward than he gets when not doing manipulation, when others get smaller, minimal in the short term (Christie and Geis, 1970, in Purnamasari, 2006:5). Personality Machiavellian having a tendency to manipulate others is very low in its appreciation to others.

The Machiavellian traits in [6] are auditors with high Machiavellian properties tend to act independently, behave unethically and are manipulatives. The tendency of Machiavellian traits is measured at a scale of Mach IV. This scale consists of 20 question items designed to measure respondent's beliefs about whether others are vulnerable or easily manipulated in personal relationships. The high Mach scale shows that a personality with low empathy, more enduring to not admit cheating, makes a good sense of misrepresentation and lack of emotion in interpersonal relationships. Turnbell (1976) in Widyaningrum \& Sarwono (2012) suggests that individuals with a high Mach scale tend to take advantage of the situation to gain personal gains.

Research by [4] and [3] found that Machiavellianism influenced the ethical decisions of profit management. Earlier research confirmed that Machiavellianism could potentially have a negative effect on the ethical decisions of accountants [3]. Individuals with high character Machiavellianism tend to agree with the behavior of profit management. Individuals with high Machiavellianism have to do all things, certain opportunistic actions to win the competition or achieve the desired goal. This logic takes us on the first hypothesis:

$\mathrm{H}_{1}$ : Accountants with high nature of Machiavellianism will tend to agree with manipulation.

Fischer \& Rosenzweig, 1995 found that managers, professional accountants and students are more tolerant with manipulation of operations versus accounting manipulation. But research by [3] found it different that professional accountants are more tolerant with accounting manipulation. [4] who did research in Indonesia did not find any influence Machiavellianism towards ethical decision on profit management and [6] also did the same research on West Sumatera, apparently in this are a still strong adhered to the indigenous system ABS-SBK making no influence the Machiavellian nature of self-accountant. This inconsistency raises new questions regarding differences in how accountants assess profit manipulation between operation manipulations and accounting manipulations. These two research hypotheses are:

$\mathrm{H}_{2}$ : The influence of Machiavellianism on the ethical decision of profit management will differ between the manipulation of the operation and the manipulation of accounting. 


\section{Methodology}

This research is an empirical test on the Machiavellianism indication in the ethical decision making of the Auditor. In this research aims to test hypotheses in the form of research question in which case researchers conduct surveys using questionnaires as their research instruments. Respondents to this research are seniors auditors in Public Accountant Office in West Sumatera. Table 1 shows the operationalization of variables formed in this study.

Table 1. Variable operationalization

\begin{tabular}{cc}
\hline Variable & \multicolumn{1}{c}{ Indicator } \\
\hline Machiavellianism & Ethical statements \\
& a. Transparency \\
& b. Honesty \\
c. Morality \\
d. Award \\
\\
The situation is dilematical \\
Ethical principles \\
a. Operating profit manipulation \\
b. Accounting profit manipulation
\end{tabular}

Source: [6], [11]

The data used in this study is the primary data sourced from questionnaires with closed questions due to the available answer options previously provided. Questionnaires are shared in the form of respondents filling themselves answers to questions (Self-administered questionnaire).Validity and Reliability not done because the instrument used adopts the full instrument of the [8].

Test normality is an important test in the statistical method of Hair et al (2006). Test normality is useful for proving data from samples that are distributed normally. In addition, test normality is also used to determine what statistical tests will be used in a study whether using a parametric test or non-parametric test. The Normal or the absence of data can be seen from the test Kolmogorov Smirnov and Shapiro Wilk.

Regression analyses aim to measure the strength of the relationship between variables and indicate the direction of the relationship between free variables and the bound variable Ghozali (2001). Test Analysis of Variance is performed to test the second hypothesis. In this study, the F test was used to determine the level of Significance The influence of independent variables simultaneous against dependent variables. The basis of its decision-making is to use a probability number of significance.

\section{Result and Discussion}

The Public Accountant office is a service company engaged in accounting auditing which is financial and can also be a consultant in providing recommendations on the results of the test. In addition to providing "opinion" products, the public Accountant office is also equipped with supporting reports to meet the needs of its clients.

The Data for this study was gathered by spreading the questionnaire at the public Accountant office. The questionnaire was delivered in the form of packages delivered directly to the 8 Public Accountant offices found as for the public Accountant office of Drs. Rinaldi Munaf, which is located at Jl. Imam Bonjol No. 8 Padang, researchers are not Find. Each 
package contains 10 questionnaire and was delivered on 16 may 2019. The questionnaire was taken in 30 May 2019. Based on the data collected, the analysis is then conducted to answer the research question. In conducting analysis used multiple regression techniques. Statistical counting activities using SPSS version 23.

Table 2. Test Normality

\begin{tabular}{|c|c|c|c|c|c|c|}
\hline \multicolumn{7}{|c|}{ Tests of Normality } \\
\hline & \multicolumn{3}{|c|}{ Kolmogorov-Smirnov ${ }^{\mathrm{a}}$} & \multicolumn{3}{|c|}{ Shapiro-Wilk } \\
\hline & Statistic & df & Sig. & Statistic & $\mathrm{df}$ & Sig. \\
\hline $\begin{array}{l}\text { Unstandardized } \\
\text { Residual }\end{array}$ & .065 & 70 & $.200^{*}$ & .98 & 70 & .360 \\
\hline
\end{tabular}

a. Lilliefors Significance Correction

*. This is a lower bound of the true significance.

Source: Processed primary Data, 2019

According to table 2 can be seen test results indicating that the data is distributed normally, because the value of Asymp Sig for all variables is greater than Alpha (0.05). As for the Shapiro - Wilk value based on the Test of Normality output, the value of significance is 0.360 . Since the value of significance is greater than 0.05 , it indicates that the data is distributed normally, thus the stage of the regression data processing can be performed.

Table 3. Summary of regression analysis results

\begin{tabular}{clc}
\hline Variable bound & \multicolumn{1}{c}{$\begin{array}{c}\text { Constants and } \\
\text { Free variables }\end{array}$} & $\begin{array}{c}\text { Regression } \\
\text { coefficient }\end{array}$ \\
\hline Ethical Attitudes $(\mathrm{Y})$ & Constant (a) & 1.019 \\
\cline { 2 - 3 } & The nature of Machiavellian $\left(\mathrm{X}_{1}\right)$ & 0.795 \\
\hline \multicolumn{2}{c}{ Source: Processed primary Data, 2019 }
\end{tabular}

Regression analysis techniques are used to know the magnitude of binding variable changes that are caused by changes occurring in free variables. Based on data processing using the help of computer program SPSS version 23.

Table 4. Coefficient test Result determination

\begin{tabular}{|c|c|c|c|c|c|}
\hline \multicolumn{6}{|c|}{ Model Summary ${ }^{b}$} \\
\hline Model & $\mathrm{R}$ & R Square & $\begin{array}{c}\text { Adjusted } \\
\text { R } \\
\text { Square } \\
\end{array}$ & $\begin{array}{l}\text { Std. Error of } \\
\text { the Estimate }\end{array}$ & Durbin-Watson \\
\hline 1 & $.813^{\mathrm{a}}$ & .661 & .651 & .83734 & 1.824 \\
\hline
\end{tabular}

A. predictors: (Constant), ethics, Machiavellian Nature

B. Dependent variables: Ethical attitude

Source: Processed primary Data, 2019 
The results of data analysis can be tested on the proposed hypothesis. Based on the calculated $\mathrm{T}$ value and the significance gained, the hypothesis test can be performed.

$\mathrm{H}_{1}$ : Senior accountants with high nature of Machiavellianism will tend to agree with the manipulation.

From the results of the analysis obtained the significance value of Machiavellian is 0.795 (greater than 0.05), meaning there is not enough evidence to support the first hypothesis. This is because West Sumatra is still strong adhering to the customary system of ABS-SBK (Adat Basandi Syara' - Syara' Bersandi Kitabullah) that affects the Machiavellian nature of the Senior accountants, can suppress or eliminate it because ABS-SBK is the doctrine that descended from Allah Almighty who is true. Innadinna Indallahil Islam (meaning: Indeed the true religion on the side of Allah SWT is Islam). It Can be concluded that the first hypothesis was rejected.

$\mathrm{H}_{2}$ : The influence of Machiavellianism on the ethical decision of profit management will differ between the manipulation of the operations and the manipulation of accounting.

From the results of analysis obtained the magnitude of value T count 2.284 (sig. $0.000<$ $0.05)$. It shows significant differences between operation manipulation and accounting manipulation. The value of $R$ Square showing 0,661 indicates the involvement of the Machiavellian variable of properties against the ethical decision of Senior accountants $66,1 \%$, while the rest is determined by another variable.

Then based on the results of a regression analysis conducted, it was discovered that the Machiavellian nature of senior accountants influence the ethical decision, can be explained: from the results of the analysis Descriptive view on the distribution of data frequencies derived from 70 respondents, it was found that an average of 10 or $28.11 \%$ of respondents answered disagreeing with the average score of 124 ratings. This means it can be said that the respondent does not feel consent to ethical attitudes that should be done.

From the results of the hypothesis testing found the absence of adequate evidence to prove a variable of Machiavellian properties affects the ethical attitudes of accountants, and the results of this research in line with research [4] and [6]. This is because West Sumatra is still strong adhered to the customary system ABS-SBK that characterizes the region of West Sumatra. This customary system that affects the nature of Machiavellian in senior accountants, can suppress or eliminate because Syara' and Kitabullah is the doctrine that descended from Allah SWT that is true (Al-Imran Verse 19).

From the results of the descriptive analysis seen in the distribution of data frequency derived from 70 respondents, it was found that only 10 respondents who had participated in the accounting education or ethics training. This means it can be said that only a few independent accountants theoretically or in training do not know the meaning of ethical accountants.

Manipulation of operations and manipulation of accounting differ significantly, this is due to an ethical education that is received indirectly forming an ethical attitude of accountants. This is in accordance with the opinions [3] and [6] reveals that the initial need for the implementation of ethical education in college is the requirement that practitioners throughout the accounting field can understand the ethical standards in auditing and implementation mechanisms and can then implement them in the workforce.

\section{Conclusion}

The nature of Machiavellianism has no effect on the ethical decision of profit management at public accountant offices in West Sumatera. Same as [6], [11], this is due to the indigenous system of ABS - SBK (Adat Basandi Syara' - Syara' Basandi Kitabullah) in West Sumatra has 
an impact on the Machiavellian nature of Senior Accountants, and the difference Between operation manipulation and accounting manipulation.

\section{Reference}

[1] C. E. Hogan, Z. Rezaee, R. A. Riley, and U. K. Velury, "Financial statement fraud: Insights from the academic literature," Auditing, vol. 27, no. 2, pp. 231-252, 2008.

[2] P. R. Murphy, "Attitude, Machiavellianism and the rationalization of misreporting," Accounting, Organ. Soc., vol. 37, no. 4, pp. 242-259, 2012.

[3] W. E. Shafer and Z. Wang, "Effects of ethical context and Machiavellianism on attitudes toward earnings management in China," Manag. Audit. J., vol. 26, no. 5, pp. 372-392, 2011.

[4] A. Sunani, B. Subroto, and Y. W. Prihatiningtias, "Do Ethical Climate and Machiavellianism Affect Ethical Perceptions of Earnings Management? Evidence from Indonesia," Glob. J. Bus. Soc. Sci. Rev., vol. 03, no. 01, pp. 131-139, 2015.

[5] A. Singhapakdi, "Ethical Perceptions of marketers: The interaction effects of machiavellianism and organizational ethical culture," J. Bus. Ethics, vol. 12, no. 5, pp. 407-418, 1993.

[6] F. Ananda and D. Zulvia, "Indikasi machiavellianism dalam pembuatan keputusan etis auditor pemula," Benefita, vol. 3, no. September, pp. 357-369, 2018.

[7] L. Jooste, "Investigating ethical perceptions of short-term earnings management practices," Int. J. Emerg. Mark., vol. 8, no. 3, pp. 282-299, 2013.

[8] T. Widyaningrum and A. E. Sarwono, "Analisis Sifat Machiavellian dan Pembelajaran Etika Terhadap Sikap Etis Akuntan dan Mahasiswa Akuntansi," J. Akunt. dan Sist. Teknol. Inf., vol. 9, no. 1, pp. 65-75, 2012.

[9] K. Rosenzweig and M. Fisher, "Is Managing Earnings Ethically Acceptable?," Manag. Account., vol. 75, no. 9, pp. 31-34, 1994.

[10] M. Fischer and K. Rosenzweig, "Attitudes of students and accounting practitioners concerning the ethical acceptability of earnings management," J. Bus. Ethics, vol. 14, pp. 433-444, 1995.

[11] F. Ananda, "Pengaruh Sifat Machiavellian dan Pembelajaran Etika terhadap Sikap Etis Akuntan (Survei pada Kantor Akuntan Publik di Sumatera Barat)," J. Ris. Manaj. dan Akunt., vol. 1, no. 2, pp. 141-149, 2014. 